\title{
Water use efficiency of net primary production in global terrestrial ecosystems
}

\author{
Lei XiA ${ }^{1,2}$, Fei WAnG ${ }^{1,2,3, *}$, Xingmin Mu ${ }^{1,2,3}$, KaI Jin ${ }^{3}$, Wenyi Sun ${ }^{1,3}$ \\ Peng GaO ${ }^{1,2,3}$ and GuanguU ZhaO ${ }^{1,2,3}$ \\ ${ }^{1}$ Institute of Soil and Water Conservation, Chinese Academy of Sciences and Ministry of Water Resources, \\ Yangling 712100, Shaanxi, China. \\ ${ }^{2}$ University of Chinese Academy of Sciences, Beijing 100049, China. \\ ${ }^{3}$ Institute of Soil and Water Conservation, Northwest A\&F University, Yangling 112100, Shaanxi, China. \\ ${ }^{*}$ Corresponding author.e-mail: wafe@ms.iswc.ac.cn
}

The carbon and water cycles of terrestrial ecosystems, which are strongly coupled via water use efficiency (WUE), are influenced by global climate change. To explore the relationship between the carbon and water cycles and predict the effect of climate change on terrestrial ecosystems, it is necessary to study the WUE in global terrestrial ecosystems. In this study, the 13-year WUE (i.e., net primary production (NPP)/evapotranspiration (ET)) of global terrestrial ecosystems was calculated based on the Moderate Resolution Imaging Spectro-radiometer (MODIS) NPP (MOD17A3) and ET (MOD16A3) products from 2000 to 2012. The results indicate that the annual average WUE decreased but not significantly, and the 13-year mean value was $868.88 \mathrm{mg} \mathrm{C} \mathrm{m}^{-2} \mathrm{~mm}^{-1}$. The variation trend of WUE value for each pixel differed greatly across the terrestrial ecosystems. A significant variation $(P<0.05)$ occurred in about $18.50 \%$ of the land surface. WUE was spatially distributed from 0 to $2541 \mathrm{mg} \mathrm{C} \mathrm{m}^{-2} \mathrm{~mm}^{-1}$, and $58.78 \%$ of the WUE values were concentrated in the interval of $600-1200 \mathrm{mg} \mathrm{C} \mathrm{m}^{-2} \mathrm{~mm}^{-1}$. The WUE increased from north to south in Africa and Oceania and from east to west in Europe and South America. Both latitudinal and longitudinal gradients existed in Asia and North America. The following trends in the WUE of different continents and Köppen-Geiger climates were observed: Europe $\left(1129.71 \mathrm{mg} \mathrm{C} \mathrm{m}^{-2}\right.$ $\mathrm{mm}^{-1}$ ) > Oceania $\left(1084.46 \mathrm{mg} \mathrm{C} \mathrm{m}^{-2} \mathrm{~mm}^{-1}\right.$ ) > Africa $\left(893.51 \mathrm{mg} \mathrm{C} \mathrm{m}^{-2} \mathrm{~mm}^{-1}\right.$ ) > South America $\left(893.07 \mathrm{mg} \mathrm{C} \mathrm{m}^{-2} \mathrm{~mm}^{-1}\right)>$ North America $\left(870.79 \mathrm{mg} \mathrm{C} \mathrm{m}^{-2} \mathrm{~mm}^{-1}\right)>$ Asia $\left(738.98 \mathrm{mg} \mathrm{C} \mathrm{m}^{-2} \mathrm{~mm}^{-1}\right)$ and warm temperate climates $\left(1094 \mathrm{mg} \mathrm{C} \mathrm{m}^{-2} \mathrm{~mm}^{-1}\right)>\operatorname{snowy}$ climates $\left(862 \mathrm{mg} \mathrm{C} \mathrm{m} \mathrm{mm}^{-1}\right)>$ arid climates $\left(785 \mathrm{mg} \mathrm{C} \mathrm{m}^{-2} \mathrm{~mm}^{-1}\right)>$ equatorial climates $\left(732 \mathrm{mg} \mathrm{C} \mathrm{m}^{-2} \mathrm{~mm}^{-1}\right)>$ polar climates (435 $\mathrm{mg} \mathrm{C} \mathrm{m}^{-2} \mathrm{~mm}^{-1}$ ). Based on the WUE value and the present or future rainfall, the maximum carbon that fixed in one region may be theoretically calculated. Also, under the background of global climatic change, WUE may be regarded as an important reference for allotting $\mathrm{CO}_{2}$ emissions offsets and carbon transactions.

\section{Introduction}

The carbon cycle, the main process coupling terrestrial ecosystems with the climate system (Cao and
Woodward 1998), plays a vital role in global climate change. The IPCC Fifth Assessment Report (AR5) indicated that global atmospheric carbon dioxide $\left(\mathrm{CO}_{2}\right)$, the most prevalent greenhouse gas,

Keywords. Water use efficiency; global terrestrial ecosystems; MODIS; net primary production; evapotranspiration; Köppen-Geiger climate classification. 
has increased by approximately $111 \mathrm{ppm}$ from the pre-industrial era (approximately $280 \mathrm{ppm}$ ) to 2011 (391 ppm) and that the radiative forcing induced by increasing carbon dioxide now reaches up to $1.68 \mathrm{~W} \mathrm{~m}^{-2}$ (IPCC 2013). According to these trends, it is expected that global warming will only escalate in severity in the 21st century if emissions of greenhouse gases are not better controlled (IPCC 2013).

Terrestrial plants fix or trap carbon dioxide via photosynthesis to produce the material and energy essential for the entire terrestrial biosphere (Cao and Woodward 1998; Beer et al. 2010; Zhao et al. $2005)$. Net primary production (NPP), defined as the difference between the amount of organic matter assimilated by plants and the costs of their autotrophic respiration (Melillo et al. 1993; Cao and Woodward 1998; Roxburgh et al. 2004), is a major component of the carbon cycle (Zhang et al. 2012) and a vital indicator for measuring ecosystem functioning (Schläpfer and Schmid 1999) and carbon fixation by vegetation (Yuan et al. 2006). NPP indicates the response of ecosystems to global climate change and human activities (Nemani et al. 2003; Roxburgh et al. 2004). NPP varies with time and shows an appreciable spatial distribution pattern at the global scale. Variations in NPP also exist among various vegetation types (Zhao et al. 2005) and are dictated by the inherent physiological features of plants (Lu and Zhuang 2010), as well as external environmental conditions, such as meteorological factors (Melillo et al. 1993), nitrogen deposition (Townsend et al. 1996; Yan et al. 2014), droughts (Zhao and Running 2010) and $\mathrm{CO}_{2}$ concentrations (Friedlingstein et al. 2006; Yan et al. 2014). Water, which is essential for photosynthesis and respiration of plants, is regarded as an extremely important factor for determining the variation in NPP (Mu et al. 2007; Nemani et al. 2003). The interaction between NPP and water can be characterized by water use efficiency (WUE) owing to its close coupling with the carbon and water cycles (Tian et al. 2010). WUE is the photosynthetic yield of plants per unit mass of water consumed. In regard to community, regional and global scales, WUE can be defined as the ratio of dry matter produced by vegetation or the NPP value to the water consumed by evapotranspiration (ET) (Hu et al. 2009; Tian et al. 2010). WUE can be expressed as the milligrams of carbon fixed by plants per millimeter of water consumed in one square meter $\left(\mathrm{mg} \mathrm{C} \mathrm{m} \mathrm{mm}^{-1}\right)$. In recent years, the concept of WUE has been widely applied to several disciplines, such as ecology, hydrology and agronomy, and this research has led to many significant and important conclusions. However, most of these studies have focussed on relatively small spatial scales, such as a field, due to the complexity of interactions, the uncertainty in influencing factors and the limited methods of measurement (Tian et al. 2010). Some studies have also been limited to one specific vegetation type. Although several studies have also been conducted at the ecosystem or regional scales in recent years (Ponton et al. 2006; Lu and Zhuang 2010; Tian et al. 2010), studies on the global scale have rarely been conducted. Global climate changes have also influenced water budgets and water resources in addition to the carbon cycle (Arnell 2004; Barnett et al. 2005; IPCC 2013); therefore, the interaction between the carbon and water cycles needs to be determined in global change research. Given such problems, it is essential to study WUE across global terrestrial ecosystems to explore the inherent relationship between the carbon and water cycles and to help predict the influences of climate change on terrestrial ecosystems.

In this study, we calculated the 13-year WUE of the global terrestrial ecosystems using remotely sensed data from the MODIS NPP products (MOD17A3) and the MODIS ET products (MOD16A3) from 2000 to 2012. Our objectives were to (1) analyze the inter-annual variable characteristics of the global WUE from 2000 to 2012, (2) discuss the spatial distribution pattern of WUE at the global scale, and (3) compare the WUE magnitude and significance of WUE for different climate types throughout the globe.

\section{Research area, data and methods}

The research area included the entire global terrestrial ecosystem where vegetation is distributed. Antarctica and the majority of Arctic regions were not included.

\subsection{Data}

The NPP datasets used in this study were obtained from the global annual MOD17A3 products (version: 055) of the NASA Earth Observation System (EOS) program, which are produced by the Numerical Terradynamic Simulation Group (NTSG)/University of Montana (UMT) (available from http://www.ntsg.umt.edu/project/mod17). The MOD17A3 product was generated using the MOD17 algorithm (supporting online material text S1 of Running et al. 2004; Zhao et al. 2005; Zhao and Running 2010), and can be used for evaluating spatial patterns of vegetation productivity, inter-annual variation and long term trend over the vegetated land surface (Turner et al. 2006). The annual NPP data used in this research were selected from 2000 to 2012, and all of them have a spatial resolution of $1 \mathrm{~km}$. The global MOD17A3 
products have been validated and results showed that there is no consistent overestimation or underestimation compared to field observed NPP globally and it is now mature enough to use the dataset in a wide variety of applications (Zhao et al. 2005, 2006). In addition, MODIS NPP was evaluated using Global Primary Production Data Initiative (GPPDI) dataset, results indicated that average NPP from 2000 through 2009 shows favourable correspondence $\left(R^{2}=0.8, P=0.00\right)$ with the GPPDI NPP for 2335 half-degree cells (Zhao and Running 2011). To date, MOD17A3 products have been widely used for numerous regional and global studies (Zhao et al. 2005, 2006; Turner et al. 2006; Zhao and Running 2010; $\mathrm{Mu}$ et al. 2013a).

The ET datasets were the global annual MOD16A3 products (available from http://ntsg. umt.edu/project/mod16) with a $1-\mathrm{km}$ resolution and an annual time step, which are also part of the NASA Earth Observation System (EOS) program but were calculated based on the improved MOD16 algorithm (Mu et al. 2011, 2013b). Validation work with ET measured at 46 eddy flux towers has shown that the global ET product agrees well $(R=0.86, P<0.01)$ with daily ET estimates based on tower eddy covariance measurements $(\mathrm{Mu}$ et al. 2011). The mean absolute error (MAE) was about $24.1 \%$ of the average measured ET, which was within the range $(10 \sim 30 \%)$ of the uncertainty of ET measurements (Mu et al. 2011). Also, the MOD16 ET has been validated with the ET values estimated from 232 global watersheds, the result indicated that the MODIS ET can explain $85 \%$ of the global variability in ET estimates for these watersheds ( $\mathrm{Mu}$ et al. 2013b). The global MOD16A3 products have now been applied to a variety of researches at the global or regional scale (Mu et al. 2011, 2013a; Sun et al. 2011; Lathuillière et al. 2012).

The vector map of the Köppen-Geiger climate classifications was the updated version (available from http://koeppen-geiger.vu-wien.ac.at/present. htm) based on two climate datasets from 1951 to 2000, including temperature data provided by the Climatic Research Unit (CRU) of the University of East Anglia and precipitation data provided by the Global Precipitation Climatology Centre (GPCC). This map will be applicable for another 100 years (Kottek et al. 2006).

\subsection{Methods}

\subsubsection{WUE of NPP}

To obtain annual average WUE values for global terrestrial ecosystems, we first derived the non-fill value to determine the annual NPP and ET from the global land surface; we then calculated the annual WUE value ( $\mathrm{mg} \mathrm{C} \mathrm{m} \mathrm{Cm}^{-1}$ ) for each grid cell using the formula (1), and the original calculated result was named as the calculated WUE $\left(\mathrm{WUE}_{\mathrm{c}}\right)$.

$$
\mathrm{WUE}_{\mathrm{c}}=\frac{\mathrm{NPP}}{\mathrm{ET}} * 1000
$$

where NPP and ET are the annual NPP value $\left(\mathrm{g} \mathrm{C} \mathrm{m}^{-2}\right)$ and the annual ET value $(\mathrm{mm})$ of each pixel, respectively.

Subsequently, we rejected the abnormally high values that were greater than $2600 \mathrm{mg} \mathrm{C} \mathrm{m}^{-2}$ $\mathrm{mm}^{-1}$. These values were regarded as no-value data points, and the remaining WUE values were used in this study. For distinguishing from the $\mathrm{WUE}_{\mathrm{c}}$, the remaining WUE values were named as the actual WUE value (WUE). The critical value of $2600 \mathrm{mg} \mathrm{C} \mathrm{m}^{-2} \mathrm{~mm}^{-1}$ was determined by the product of $5000 \mathrm{mg} \mathrm{C} \mathrm{m}^{-2} \mathrm{~mm}^{-1}$, which is the marginal WUE value calculated based on gross primary production (GPP) and ET data (Lu and Zhuang 2010), and 0.52, which is the average NPP/GPP ratio value (Zhang et al. 2009). Finally, the statistics for NPP, ET, $\mathrm{WUE}_{\mathrm{c}}$ and WUE were calculated. The mean value was calculated as the mean of all pixels in a given year.

To calculate the 13-year average WUE, we calculated the average value for each individual grid cell from 2000 to 2012 and got a spatial distribution map of global mean WUE value. We then computed the mean of all pixels in the above map and the result was the 13-year average WUE.

\subsubsection{The simple linear regression method}

In this study, the simple linear regression method (Ma et al. 2003) was used to analyze the annual variability in the WUE and the variable trend of each WUE pixel from 2000 to 2012. The slope was calculated as:

$$
k=\frac{13 * \sum_{i=1}^{13} i \mathrm{WUE}_{i}-\sum_{i=1}^{13} i \sum_{i=1}^{13} \mathrm{WUE}_{i}}{13 * \sum_{i=1}^{13} i^{2}-\left(\sum_{i=1}^{13} i\right)^{2}}
$$

where $i$ represents the year, $i$ in 2000 equals $1, i$ in 2001 equals 2, and so on; $\mathrm{WUE}_{i}$ is the mean WUE value in the $i$ th year; and $k$ is the slope of the trend line. If $k$ is greater than 0 , then the trend is increasing; otherwise the trend is decreasing. The magnitude of $k$ represents the rate of change, i.e., a greater absolute value of $k$ corresponds to a more rapid variation in the WUE.

Also, F-test was conducted to test the significance of variation trend for the pixels whose slopes were not equal to 0 . Unlike the value of $k$, the significance represents the confidence degree of the variation trend. According to the tested results, 
trends of WUE values were divided into six levels: highly significant decrease $(P<0.01)$; significant decrease $(0.01<P<0.05)$; decrease but not significant $(P>0.05)$; increase but not significant $(P>0.05)$; significant increase $(0.01<P<0.05)$; highly significant increase $(P<0.01)$.

\subsubsection{Statistical analysis of the WUE in each continent and each climate type}

The mean WUE value in each continent was calculated as the average values of all grid cells in corresponding continent. To determine the statistics for the WUE in each climate type, we first extracted the vector maps of five climate zones and 14 climate types from the digital vector map of the KöppenGeiger climate classification. We then extracted the 13-year average WUE values from the extracted vector maps and calculated the WUE statistics for all the pixels in each climate zone and type.

\section{Results}

\subsection{The temporal variability of the WUE from 2000 to 2012}

The NPP and ET varied greatly between different vegetation and climate conditions. The annual average NPP and ET from each cell and their variation coefficients $(\mathrm{CV})$ are shown in table 1. The CVs for the NPP, ET and WUE among cells were $0.783,0.704$ and 0.430 , respectively, indicating that the differences in the NPP and ET among cells were much larger than those of the WUE. The 13-year average values of NPP, ET and WUE were $448.97 \mathrm{~g} \mathrm{C} \mathrm{m}^{-2}, 520.05 \mathrm{~mm}$, and
$868.88 \mathrm{mg} \mathrm{C} \mathrm{m}^{-2} \mathrm{~mm}^{-1}$, respectively. The mean WUE value for each year varied from 849.26 (in 2010) to $893.36 \mathrm{mg} \mathrm{C} \mathrm{m}^{-2} \mathrm{~mm}^{-1}$ (in 2011). The linear regression analysis of the annual data showed that from 2000 to 2012, the WUE showed a decreasing trend, and both NPP and ET tended to increase. Also, the ET increased significantly $(P<0.05)$, whereas the trends of both NPP and WUE were not significant. Further analysis indicated that the annual mean WUE showed a highly significant decrease $(P<0.01)$ from 2000 to 2010 , and since then WUE began to increase.

Although the annual mean WUE values did not show a significant trend as a whole, the variation trend of WUE value for each pixel differed greatly across the land surface. The rate of change in the WUE for each pixel from 2000 to 2012 based on the simple linear regression analysis is shown in figure 1(a). Also, in order to describe the confidence degree of the WUE variable trend, the significance of WUE trend was classified into six categories (figure 1b), and both the pixel count and the percentage of the total number of Earth's pixels were calculated for each category (table 2). WUE values in most areas of the global terrestrial ecosystem ( $81.50 \%$ of the Earth's total pixels) showed nonsignificant variation during the 13 -year period. The areas where the WUE showed a highly significant decrease and significant decrease accounted for 3.47 and $4.22 \%$ of the Earth's total pixels, respectively. These areas mainly distributed throughout much of central South America, the southern areas of the Sahara Desert, Eastern Europe, the Malay Archipelago and part of Australia. The significant $(6.18 \%)$ and highly significant increasing trend $(4.63 \%)$ in the WUE mainly occurred in the Congo River Basin in Africa and Loess Plateau and Tibet

Table 1. The statistics of annual mean NPP, ET and WUE in global terrestrial ecosystems from 2000 to 2012.

\begin{tabular}{|c|c|c|c|c|c|c|}
\hline \multirow[b]{2}{*}{ Year } & \multicolumn{2}{|c|}{ NPP } & \multicolumn{2}{|c|}{$\mathrm{ET}$} & \multicolumn{2}{|l|}{ WUE } \\
\hline & $\begin{array}{c}\text { Mean } \\
\left(\mathrm{g} \mathrm{C} \mathrm{m}^{-2}\right)\end{array}$ & $\mathrm{CV}$ & $\begin{array}{l}\text { Mean } \\
(\mathrm{mm})\end{array}$ & $\mathrm{CV}$ & $\begin{array}{c}\text { Mean } \\
\left(\mathrm{mg} \mathrm{C} \mathrm{m}^{-2} \mathrm{~mm}^{-1}\right)\end{array}$ & $\mathrm{CV}$ \\
\hline 2000 & 453.48 & 0.818 & 515.43 & 0.716 & 881.77 & 0.478 \\
\hline 2001 & 448.34 & 0.808 & 512.00 & 0.719 & 882.14 & 0.480 \\
\hline 2002 & 439.32 & 0.835 & 511.66 & 0.745 & 876.69 & 0.498 \\
\hline 2003 & 446.01 & 0.813 & 516.41 & 0.719 & 879.56 & 0.469 \\
\hline 2004 & 453.71 & 0.811 & 516.69 & 0.730 & 889.43 & 0.471 \\
\hline 2005 & 436.70 & 0.795 & 514.08 & 0.713 & 870.24 & 0.480 \\
\hline 2006 & 446.93 & 0.794 & 523.08 & 0.712 & 872.08 & 0.466 \\
\hline 2007 & 445.34 & 0.792 & 528.69 & 0.704 & 858.53 & 0.469 \\
\hline 2008 & 447.43 & 0.801 & 520.69 & 0.708 & 869.86 & 0.471 \\
\hline 2009 & 449.24 & 0.803 & 521.85 & 0.729 & 872.62 & 0.463 \\
\hline 2010 & 442.71 & 0.785 & 530.20 & 0.698 & 849.26 & 0.464 \\
\hline 2011 & 459.73 & 0.767 & 522.92 & 0.698 & 893.36 & 0.453 \\
\hline 2012 & 446.14 & 0.788 & 514.52 & 0.718 & 891.09 & 0.456 \\
\hline Average & 448.97 & 0.783 & 520.05 & 0.704 & 868.88 & 0.430 \\
\hline
\end{tabular}




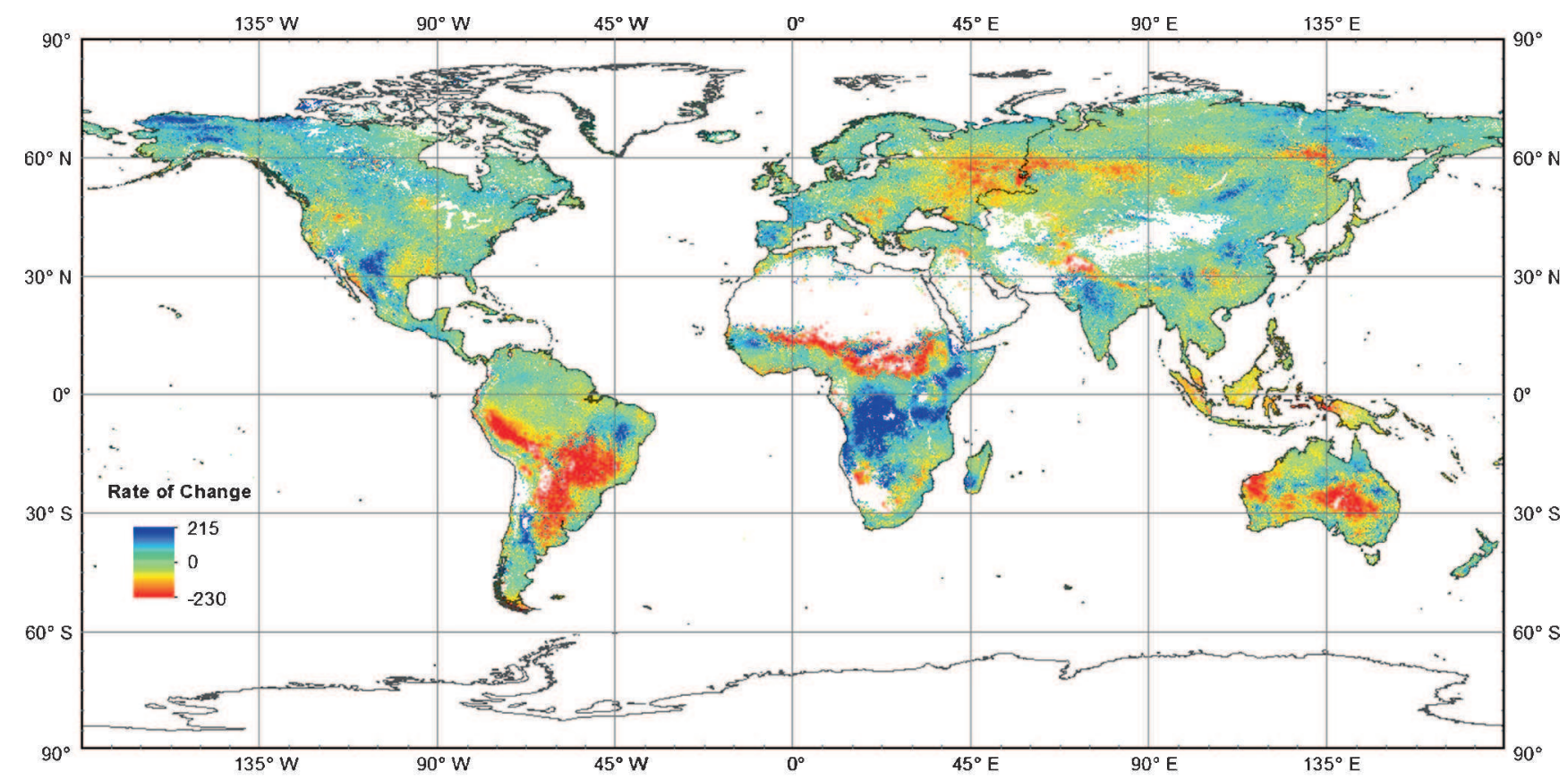

(a)



(b)

Figure 1. Spatial distribution of WUE trend from 2000 to 2012 in global terrestrial ecosystems. (a) Rate of change in the WUE for each pixel. (b) Significance of WUE variation trend.

Plateau in China. Besides, the north and southwest areas of North America, Western Europe and the northeast areas of Asia are also included.

\subsection{Spatial distribution of the WUE}

Influenced by a series of external environmental factors, such as the temperature and radiation, the WUE showed a strong spatial distribution across the entire surface of the Earth. By calculating the average WUE value of each pixel from 2000 to 2012, the 13-year mean WUE values were acquired and are shown in figure 2.

The calculated global terrestrial WUE ranged from 0 to $2541 \mathrm{mg} \mathrm{C} \mathrm{m}^{-2} \mathrm{~mm}^{-1}$. As expected, the WUE presented pronounced latitudinal and longitudinal gradients on every continent. In Africa and Oceania, the WUE gradually increased from north to south, running parallel along the latitudes. Similarly, an obvious increase with longitude 
from east to west can be observed in Europe and South America. However, the patterns in Asia and North America are more complex, in that the WUE appears to increase in a southern direction in areas above the latitude of $50^{\circ} \mathrm{N}$, whereas below this latitude, the WUE presents a longitudinal increasing trend towards the east in Asia and increases from the inland out to the coasts in North America.

To understand the spatial distribution of the WUE, the values were divided into six levels: low $\left(<300 \mathrm{mg} \mathrm{C} \mathrm{m}^{-2} \mathrm{~mm}^{-1}\right)$, slightly low (300-600 mg C $\left.\mathrm{m}^{-2} \mathrm{~mm}^{-1}\right)$, medium $\left(600-900 \mathrm{mg} \mathrm{C} \mathrm{m}^{-2}\right.$ $\mathrm{mm}^{-1}$ ), slightly high (900-1200 $\left.\mathrm{mg} \mathrm{C} \mathrm{m}^{-2} \mathrm{~mm}^{-1}\right)$, high (1200-1500 $\mathrm{mg} \mathrm{C} \mathrm{m}^{-2} \mathrm{~mm}^{-1}$ ) and extremely high (>1500 $\mathrm{mg} \mathrm{C} \mathrm{m}^{-2} \mathrm{~mm}^{-1}$ ) according to their distribution. The pixel counts and percentages for each group and their specific distributions are presented in table 3 and figure 3 .

As shown in table 3, the global WUE values were concentrated in the $600-900 \mathrm{mg} \mathrm{C} \mathrm{m}^{-2} \mathrm{~mm}^{-1}$

Table 2. The statistic on significance of WUE variation trend from 2000 to 2012.

\begin{tabular}{lrr}
\hline Significance & Pixel count & $\begin{array}{c}\text { Percentage } \\
(\%)\end{array}$ \\
\hline Highly significant decrease & 5842210 & 3.47 \\
Significant decrease & 7113091 & 4.22 \\
Decrease but not significant & 61753106 & 36.61 \\
Increase but not significant & 75720949 & 44.89 \\
Significant increase & 10423165 & 6.18 \\
Highly significant decrease & 7814205 & 4.63 \\
Total & 168666726 & 100.00
\end{tabular}

interval, which corresponds to more than one third $(34.58 \%)$ of the Earth's land surface, followed by the slightly high category with $24.20 \%$. The $<300$ $\mathrm{mg} \mathrm{C} \mathrm{m} \mathrm{mm}^{-1}$ and $>1500 \mathrm{mg} \mathrm{C} \mathrm{m}^{-2} \mathrm{~mm}^{-1}$ categories were the least common WUE groups at $5.74 \%$ and $5.17 \%$, respectively. The pixel numbers of the slightly low and extremely high WUE categories were similar at 16.55 and $13.76 \%$, respectively.

As shown in figure 3, the WUE values in the 600$1200 \mathrm{mg} \mathrm{C} \mathrm{m}^{-2} \mathrm{~mm}^{-1}$ interval (the medium and slightly high levels), which accounted for $58.78 \%$ of the entire land surface, were distributed throughout the globe but mainly occurred inland rather than near the coasts. Conversely, the WUE values of the other levels were mainly distributed in areas along the coasts and showed a latitudinal distribution. In the Northern Hemisphere, WUE values less than $600 \mathrm{mg} \mathrm{C} \mathrm{m} \mathrm{mm}^{-1}$ (the slightly low and low levels) occurred in coastal regions, both

Table 3. The classification level and number of pixel for the 13-year mean WUE.

\begin{tabular}{lcrr}
\hline & WUE interval & \multicolumn{2}{r}{ Percentage } \\
Level & $\left(\mathrm{mg} \mathrm{C} \mathrm{m}^{-2} \mathrm{~mm}^{-1}\right)$ & Pixel count & $(\%)$ \\
\hline Low & $<300$ & 9690193 & 5.74 \\
Slightly low & $300-600$ & 27945286 & 16.55 \\
Medium & $600-900$ & 58376720 & 34.58 \\
Slightly high & $900-1200$ & 40864654 & 24.20 \\
High & $1200-1500$ & 23222909 & 13.76 \\
Extremely high & $>1500$ & 8728978 & 5.17 \\
Total & & 168828740 & 100.00 \\
\hline
\end{tabular}

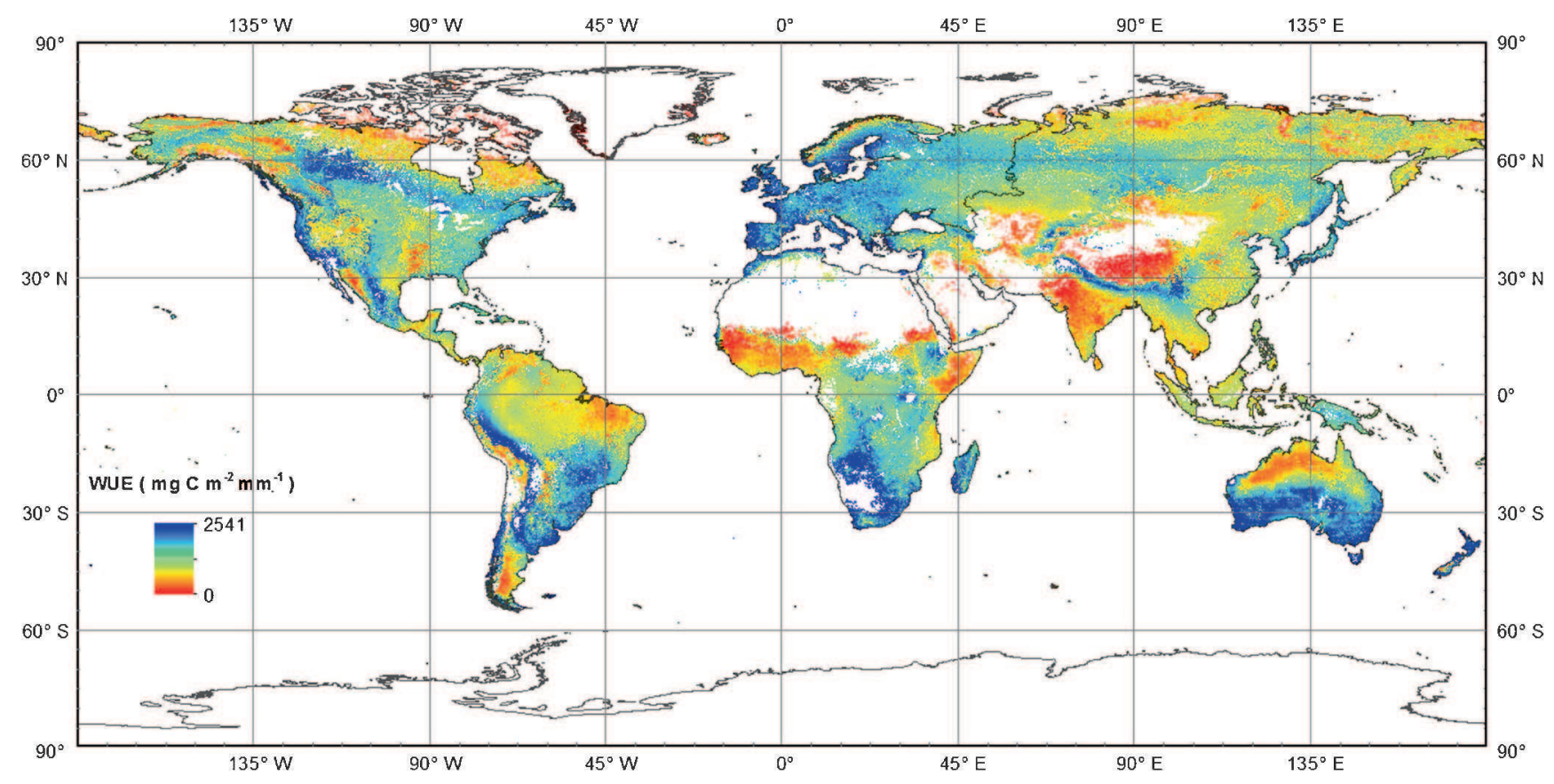

Figure 2. Mean WUE of each pixel over the 13-year study period. 


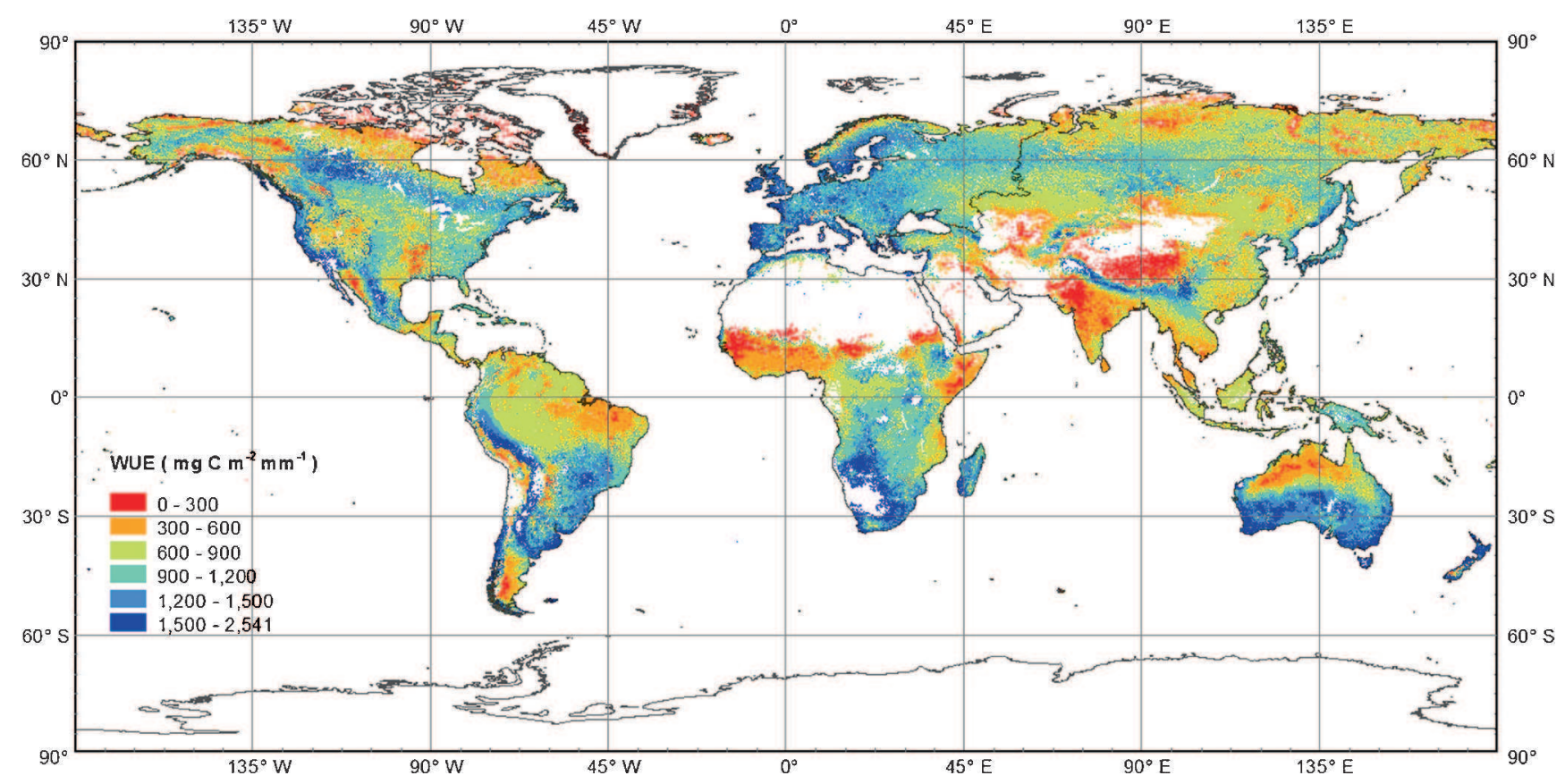

Figure 3. Classification of the mean WUE values of the 13-year average classified WUE.

at low $\left(0-30^{\circ} \mathrm{N}\right)$ and high latitudes $\left(>60^{\circ} \mathrm{N}\right)$, with the exception of the Baltic Sea coasts where the WUE values were categorized as high. Correspondingly, WUE values in the mid-latitude $\left(30^{\circ}-60^{\circ} \mathrm{N}\right)$ coasts were $>1200 \mathrm{mg} \mathrm{C} \mathrm{m}^{-2} \mathrm{~mm}^{-1}$ (the high and extremely high levels), with the exception of certain northeastern coastal regions of North America, which had slightly lower WUE values. In the Southern Hemisphere, there was a division in the distribution of WUE values at the latitude of $20^{\circ} \mathrm{S}$. WUE values $<600 \mathrm{mg} \mathrm{C} \mathrm{m}{ }^{-2} \mathrm{~mm}^{-1}$ were distributed in coastal areas above this divide, and values $>1200 \mathrm{mg} \mathrm{C} \mathrm{m}^{-2} \mathrm{~mm}^{-1}$ were found below this line. It is also important to note that a small number of extremely high WUE values occurred in the regions along the Himalayas, the Yun-gui Plateau and the Mexican Plateau.

As expected, the magnitude of the WUE varied among the continents (figure 4). Europe had the highest average WUE of $1129.71 \mathrm{mg} \mathrm{C} \mathrm{m}^{-2}$ $\mathrm{mm}^{-1}$, whereas the lowest average WUE $(738.98$ $\mathrm{mg} \mathrm{C} \mathrm{m}^{-2} \mathrm{~mm}^{-1}$ ) occurred in Asia. In Oceania, Africa, South America and North America, the average WUE values were 1084.46, 893.51, 893.07, and $870.79 \mathrm{mg} \mathrm{C} \mathrm{m} \mathrm{mm}^{-1}$, respectively. The average WUE ( $870.79 \mathrm{mg} \mathrm{C} \mathrm{m}^{-2} \mathrm{~mm}^{-1}$ ) in North America was close to the global average WUE at $868.88 \mathrm{mg} \mathrm{C} \mathrm{m}^{-2} \mathrm{~mm}^{-1}$.

Additionally, differences in the WUE composition existed within each continent. As shown in figure 4, WUE values in the $0-300 \mathrm{mg} \mathrm{C} \mathrm{m}^{-2} \mathrm{~mm}^{-1}$ interval had the lowest percentage in Europe, Africa, Oceania and South America, whereas the lowest percentage of WUE values in the interval
$>1500 \mathrm{mg} \mathrm{C} \mathrm{m} \mathrm{mm}^{-1}$ were observed in Asia and North America. WUE values were concentrated in the $600-900 \mathrm{mg} \mathrm{C} \mathrm{m}{ }^{-2} \mathrm{~mm}^{-1}$ interval in Asia, South America and North America, the 900-1200 $\mathrm{mg} \mathrm{C} \mathrm{m}^{-2} \mathrm{~mm}^{-1}$ interval in Europe and Africa and the $1200-1500 \mathrm{mg} \mathrm{C} \mathrm{m}^{-2} \mathrm{~mm}^{-1}$ interval in Oceania.

\subsection{WUE for different climate types}

Based on the Köppen-Geiger climate classification, we determined the WUE values for each climate type, as listed in table 4.

The results revealed that the highest WUE values occurred in the warm temperate climates, followed by the snow, arid, equatorial and polar climates. Among these types, the $\mathrm{C}$ types, in particular Cs, had the highest WUE values, with a median of up to $1100 \mathrm{mg} \mathrm{C} \mathrm{m} \mathrm{mm}^{-1}$. The lowest median WUE values were 13 and $436 \mathrm{mg} \mathrm{C} \mathrm{m}{ }^{-2} \mathrm{~mm}^{-1}$, which occurred in the EF and ET types, respectively. Additionally, the median WUE in the BW (882 $\mathrm{mg} \mathrm{C} \mathrm{m}^{-2} \mathrm{~mm}^{-1}$ ) and Df $\left(889 \mathrm{mg} \mathrm{C} \mathrm{m}^{-2}\right.$ $\mathrm{mm}^{-1}$ ) types were nearly equal to the annual average WUE (table 1).

\section{Discussion}

To understand the relationship between the carbon cycle and the water cycle as well as the response of 


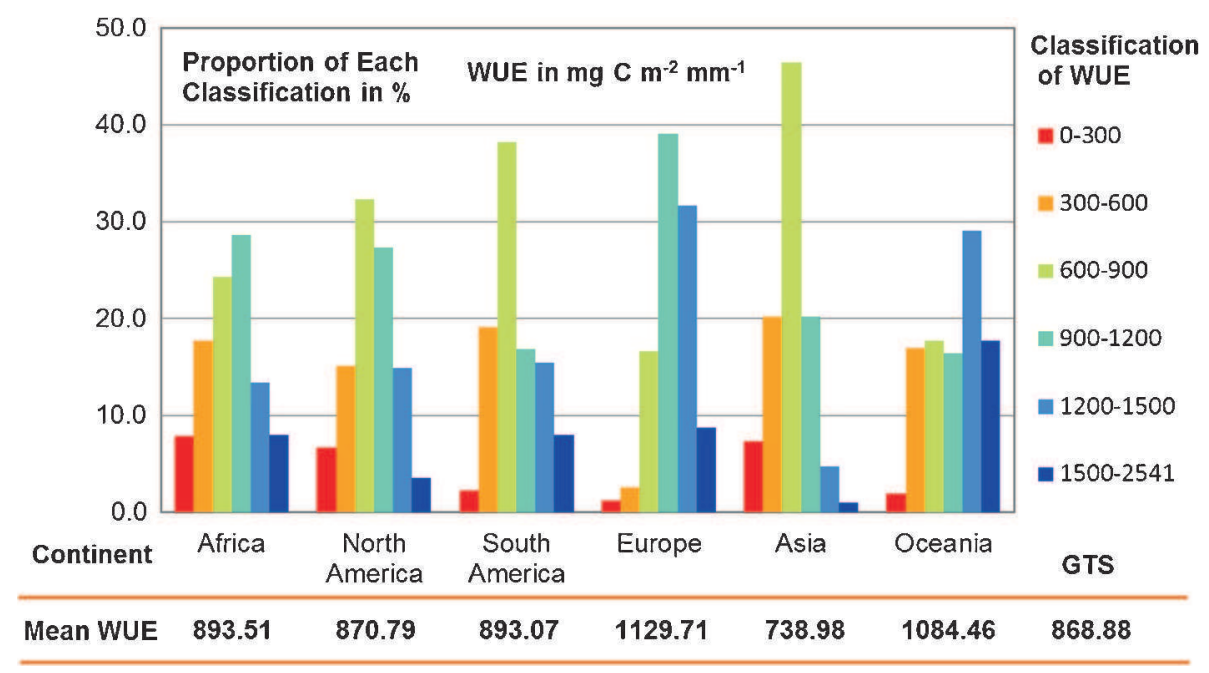

Figure 4. A schematic figure of the WUE in each continent.

Table 4. The statistic WUE ( $\left.m g \mathrm{C} \mathrm{m}^{-2} \mathrm{~mm}^{-1}\right)$ of each climate type based on Köppen-Geiger climate classification.

\begin{tabular}{|c|c|c|c|c|c|}
\hline Type & Description & Pixel count & $\begin{array}{c}\text { Mean } \\
\left(\mathrm{mg} \mathrm{C} \mathrm{m}^{-2} \mathrm{~mm}^{-1}\right)\end{array}$ & $\begin{array}{c}\text { Median } \\
\left(\mathrm{mg} \mathrm{C} \mathrm{m}^{-2} \mathrm{~mm}^{-1}\right)\end{array}$ & $\mathrm{CV}$ \\
\hline $\mathrm{A}$ & Equatorial climates & 32868338 & 779.08 & 732 & 0.385 \\
\hline Af & Equatorial rainforest, fully humid & 7193813 & 791.01 & 736 & 0.296 \\
\hline Am & Equatorial monsoon & 5673066 & 730.38 & 671 & 0.351 \\
\hline As & Equatorial savannah with dry summer & 823563 & 631.50 & 620 & 0.396 \\
\hline Aw & Equatorial savannah with dry winter & 19177981 & 795.35 & 760 & 0.415 \\
\hline B & Arid climates & 28664472 & 860.94 & 785 & 0.526 \\
\hline BW & Desert climate & 9023213 & 892.21 & 882 & 0.570 \\
\hline $\mathrm{BS}$ & Steppe climate & 19641824 & 846.57 & 766 & 0.501 \\
\hline $\mathrm{C}$ & Warm temperate climates & 28708324 & 1097.44 & 1094 & 0.364 \\
\hline $\mathrm{Cf}$ & Warm temperate climate, fully humid & 16732377 & 1116.02 & 1136 & 0.338 \\
\hline Cs & Warm temperate climate with dry summer & 5090065 & 1148.93 & 1137 & 0.451 \\
\hline $\mathrm{Cw}$ & Warm temperate climate with dry winter & 6885504 & 1014.21 & 1004 & 0.328 \\
\hline $\mathrm{D}$ & Snow climates & 67851824 & 885.24 & 862 & 0.322 \\
\hline Df & Snow climate, fully humid & 57913912 & 905.52 & 889 & 0.315 \\
\hline Ds & Snow climate with dry summer & 1759250 & 718.40 & 682 & 0.416 \\
\hline Dw & Snow climate with dry winter & 8178192 & 777.51 & 756 & 0.304 \\
\hline $\mathrm{E}$ & Polar climates & 10494100 & 443.82 & 435 & 0.661 \\
\hline $\mathrm{EF}$ & Frost climate & 7580 & 21.66 & 13 & 1.155 \\
\hline ET & Tundra climate & 10485184 & 444.10 & 436 & 0.660 \\
\hline
\end{tabular}

terrestrial ecosystems to global climate change, it is essential to clarify the global patterns of WUE.

WUE is dependent on two variables, NPP and ET, which are influenced by numerous meteorological factors, including temperature, precipitation and solar radiation. Additionally, plant type is an important determining factor for NPP and ET. Climate, land-use and land-cover change also influence NPP and ET (Levy et al. 2004; Liu et al. 2008; Zhao and Yu 2008). Therefore, all of these factors may have temporal and spatial effects on the magnitude and variability of the WUE.

During the 13-year period assessed in this study, the temporal variability of the WUE in different areas differed owing to simultaneous changes in both the NPP and ET, meaning that a change in only NPP or ET may not be responsible for variability in the WUE. For example, in regions such as the southern Sahara Desert, the east coast of Australia and the Brazil Plateau, there was no 
increase in the WUE although the NPP rapidly increased, which can be explained by the stronger increase in the ET. In certain areas, including Southeast Asia, the Amazon plain and the plains of La Plata, there was no obvious change in the ET, whereas the WUE showed a decreasing trend, which may be attributed to rapid decreases in the NPP.

Given the challenge of meeting the food demand from sharply increasing populations faced with limited water resources (Wallace 2000), it is necessary to find appropriate and realistic strategies to produce a large amount of biomass with little water loss, i.e., to pursue large WUE values. In the aforementioned regions where we observed no increase or even a decrease in the WUE, the determining factors for WUE should be delineated to allow us to control the current trend and to improve the WUE values. However, it must be noted that pursuing a large WUE does not mean seeking an increasing WUE trend, because as mentioned above, variations of WUE values are controlled by external factors. Study of Lu and Zhuang (2010) indicated that WUE did not show a monotonously decreasing trend but a two-stage pattern in response to water stress in the conterminous United States. That is, WUE tended to increase under moderate drought condition, and decreased when severe and exceptional drought occurred. Also, Yan et al. (2014) analyzed the response of WUE from a mesocosm with five subtropical tree species to $\mathrm{CO}_{2}$ enhancement and $\mathrm{N}$ addition and showed that both increasing $\mathrm{N}$ deposition and increasing $\mathrm{CO}_{2}$ concentration had influence on WUE. Therefore, it is not always good news in the areas where WUE showed an increasing pattern because some negative factors like drought and $\mathrm{CO}_{2}$ concentration may be the reason for the increase of WUE. Reasons of both increasing and decreasing WUE trends for the specific areas or ecosystems should be analyzed in further study.

Distribution of the WUE differs from that of both the NPP and ET. High WUE values do not always occur in regions where NPP values are high or where ET values are low. Some areas where the NPP is slightly low and ET is significantly low, may also have high WUE values. Similarly, some regions with a higher NPP may have a lower WUE because the ET is much higher. Therefore, both high production and low water expense should be taken into account.

WUE showed apparent latitudinal and longitudinal gradients in each continent. It is noted that the annual mean rainfall, the annual mean temperature and the annual total amount of solar radiation express regular distribution patterns. Also, as mentioned above, all of these factors influence the magnitude and distribution of both NPP and ET values. Therefore, WUE is inevitably correlated with each of them in some regions. In addition, in the plateau areas, such as Tibet Plateau and Brazilian Plateau, WUE tend to increase towards the surrounding areas, which may be explained by the variation of altitude. However, the spatial distribution of WUE is actually controlled by the comprehensive impact of all above factors, and reasons for every specific region need to be deeply researched.

Over large spatial scales, the distribution of natural vegetation is mainly influenced by climate, resulting in a close association with these parameters (De Castro et al. 2007). The Köppen-Geiger climate classes, which are based on meteorological factors such as precipitation and air temperature (Kottek et al. 2006), are generally correlated with vegetation classes. In this study, the magnitudes of the WUE in different climate classes were compared. The WUE in the tundra climate type (ET), corresponding to the tundra vegetation class (De Castro et al. 2007), was far lower than in the other types. This result is similar to a previous report that the WUE (defined as the Gross Ecosystem Production (GEP) divided by the ET) of tundra was lower than that of other vegetation types throughout the world (Law et al. 2002). Additionally, we found that the warm temperate climate type with dry summers (Cs), corresponding to the hard-leaved evergreen trees and shrubs vegetation class (De Castro et al. 2007), had the highest WUE. Similarly, Lu and Zhuang (2010) analyzed terrestrial ecosystem WUEs (i.e., GPP/ET) in the conterminous United States and found that the highest WUE occurred in evergreen broad-leaf forests.

The spatial distribution of WUE indicates that the amount of fixed carbon differs across the global land surface when consuming equal volume of water. The maximum amount of fixed carbon in one region may be theoretically determined based on the WUE and the gross water resources. Additionally, both the spatial distribution and the amount of precipitation are influenced by climate change. Thus, rainfall and water resources may be calculated based on different scenarios (Alcamo et al. 2007; Loukas et al. 2007; IPCC 2013) and the fixed carbon of one region can be predicted using the WUE values and the predicted water resources.

The actual and potential levels of carbon fixation in countries and regions should be considered when allotting $\mathrm{CO}_{2}$ emission offsets. Additionally, with the continuous increase in atmospheric $\mathrm{CO}_{2}$ and the growth of a global carbon market (Kossoy and Guigon 2012), WUE values may be regarded as a reference for carbon transactions. 


\section{Conclusions}

Based on the MODIS NPP (MOD17A3) and MODIS ET (MOD16A3) products from 2000 to 2012, we calculated the 13-year WUE of global terrestrial ecosystems, explored the spatial distribution pattern of 13-year average WUE, and compared the magnitudes of WUE for different continents and climate types.

Our research indicated that the 13-year average WUE was $868.88 \mathrm{mg} \mathrm{C} \mathrm{m}^{-2} \mathrm{~mm}^{-1}$ and the decrease in the annual average WUE was insignificant. The global terrestrial WUE was spatially distributed from 0 to $2541 \mathrm{mg} \mathrm{C} \mathrm{m} \mathrm{mm}^{-1}$. The WUE increased from north to south in Africa and Oceania and from east to west in Europe and South America. Latitudinal and longitudinal gradients of WUE existed in Asia and North America. There were $58.78 \%$ of the WUE values varying from 600 to $1200 \mathrm{mg} \mathrm{C} \mathrm{m}^{-2} \mathrm{~mm}^{-1}$ interval and mainly occurred inland. WUE values in other intervals were mainly distributed in coastal areas. The highest WUE values were in Europe and the warm temperate climates, whereas the lowest values distributed across Asia and the polar climates.

The ecosystem with higher WUE could produce more biomass with the same volume of water, and it should be considered as a feasible way to select proper vegetations to increase the accumulation of biomass and to fix more carbon. The actual and potential levels of carbon fixation in countries and regions should be considered when allotting $\mathrm{CO}_{2}$ emission offsets and WUE values may be regarded as a reference for carbon transactions.

\section{Acknowledgements}

This research was supported by the National Natural Science Foundation of China [41171420 and 41271295], the Key Research Program of the Chinese Academy of Sciences [KZZD-EW-04], and the West Light Foundation of The Chinese Academy of Sciences [2013-165-04] and the Chinese Fundamental Research Funds for the Central Universities [QN2011150]. Authors thank Wenshuai Zhang, Yi He, Qiao Jiao and Jason Stuka for discussions and Jason Stuka for English language editing.

\section{References}

Alcamo J, Flörke M and Märker M 2007 Future longterm changes in global water resources driven by socioeconomic and climatic changes; Hydrol. Sci. J. 52(2) $247-275$.
Arnell N W 2004 Climate change and global water resources: SRES emissions and socio-economic scenarios; Global Environ. Change 14(1) 31-52.

Barnett T P, Adam J C and Lettenmaier D P 2005 Potential impacts of a warming climate on water availability in snow-dominated regions; Nature 438 303-309.

Beer C, Reichstein M, Tomelleri E, Ciais P, Jung M, Carvalhais N, Rödenbeck C, Arain M A, Baldocchi D and Bonan G B 2010 Terrestrial gross carbon dioxide uptake: Global distribution and covariation with climate; Science 329 834-838.

Cao M and Woodward F I 1998 Dynamic responses of terrestrial ecosystem carbon cycling to global climate change; Nature 393 249-252.

De Castro M, Gallardo C, Jylha K and Tuomenvirta H 2007 The use of a climate-type classification for assessing climate change effects in Europe from an ensemble of nine regional climate models; Climatic Change 81(1) 329-341.

Friedlingstein P, Cox P, Betts R, Bopp L, Von Bloh W, Brovkin V, Cadule P, Doney S, Eby M and Fung I 2006 Climate-carbon cycle feedback analysis: Results from the $\mathrm{C}^{4} \mathrm{MIP}$ model intercomparison; J. Climate 19(14) 3337-3353.

Hu Z M, Yu G R, Wang Q F and Zhao F H 2009 Ecosystem level water use efficiency: A review; Acta Ecologica Sinica 29 1498-1507 (in Chinese).

IPCC 2013 Summary for Policymakers; In: Climate Change 2013: The Physical Science Basis. Contribution of Working Group I to the Fifth Assessment Report of the Intergovernmental Panel on Climate Change (eds) Stocker T F, Qin D, Plattner G K, Tignor M, Allen S K, Boschung J, Nauels A, Xia Y, Bex V and Midgley $\mathrm{P}$ M, Cambridge University Press, Cambridge, United Kingdom and New York, NY, USA (http://www.ipcc.ch/pdf/assessment-report/ ar5/wg1/WGIAR5_SPM_brochure_en.pdf).

Kossoy A and Guigon P 2012 State and trends of the carbon market 2012 World Bank, Washington, DC (https:// openknowledge.worldbank.com/handle/10986/13336).

Kottek M, Grieser J, Beck C, Rudolf B and Rubel F 2006 World map of the Koppen-Geiger climate classification updated; Meteorol. Z. 15(3) 259-263.

Lathuillière M J, Johnson M S and Donner S D 2012 Water use by terrestrial ecosystems: Temporal variability in rainforest and agricultural contributions to evapotranspiration in Mato Grosso Brazil; Environ. Res. Lett. $7(\mathbf{2})$ 024024 .

Law B, Falge E, Gu L V, Baldocchi D, Bakwin P, Berbigier P, Berbigier P, Davis K, Dolman A, Falk M and Fuentes J 2002 Environmental controls over carbon dioxide and water vapor exchange of terrestrial vegetation; Agr. Forest. Meteorol. 113(1) 97-120.

Levy P, Friend A, White A and Cannell M 2004 The influence of land use change on global-scale fluxes of carbon from terrestrial ecosystems; Clim. Change 67(2-3) 185-209.

Liu M, Tian H, Chen G, Ren W, Zhang C and Liu J 2008 Effects of land-use and land-cover change on evapotranspiration and water yield in China during 1900-2000; J. Am. Water Resour. Assoc. 44(5) 1193-1207.

Loukas A, Vasiliades L and Tzabiras J 2007 Evaluation of climate change on drought impulses in Thessaly, Greece; European Water 17(18) 17-28.

Lu X and Zhuang Q 2010 Evaluating evapotranspiration and water-use efficiency of terrestrial ecosystems in the conterminous United States using MODIS and AmeriFlux data; Remote Sens. Environ. 114(9) 1924-1939.

Ma M G, Dong L X and Wang X M 2003 Study on the dynamically monitoring and simulating the vegetation 
cover in northwest China in the past 21 years; J. Glaciol. Geocryol. 25 232-236 (in Chinese, http://210.72.80.159/ jweb_bcdt/CN/Y2003/V25/I2/232).

Melillo J M, McGuire A D, Kicklighter D W, Moore B, Vorosmarty C J and Schloss A L 1993 Global climate change and terrestrial net primary production; Nature $363234-240$.

Mu Q, Zhao M, Heinsch F A, Liu M, Tian H and Running S W 2007 Evaluating water stress controls on primary production in biogeochemical and remote sensing based models; J. Geophys. Res. 112 G01012.

Mu Q, Zhao M and Running S W 2011 Improvements to a MODIS global terrestrial evapotranspiration algorithm; Remote Sens. Environ. 115(8) 1781-1800.

Mu Q, Zhao M, Kimball J S, McDowell N G and Running S W 2013a A remotely sensed global terrestrial drought severity index; Bull. Am. Meteorol. Soc. 94(1) 83-98.

$\mathrm{Mu}$ Q, Zhao $\mathrm{M}$ and Running S W 2013b MODIS Global Terrestrial Evapotranspiration (ET) Product (NASA MOD16A2/A3) Collection 5; NASA Headquarters; 11/2013, Missoula (https://secure.ntsg.umt.edu/ publications/2013/MZR13/MOD16_ATBD.pdf).

Nemani R R, Keeling C D, Hashimoto H, Jolly W M, Piper S C, Tucker C J, Myneni R B and Running S W 2003 Climate-driven increases in global terrestrial net primary production from 1982 to 1999; Science 300 1560-1563.

Ponton S, Flanagan L B, Alstad K P, Johnson B G, Morgenstern K, Kljun N, Black T A and Barr A G 2006 Comparison of ecosystem water-use efficiency among Douglas-fir forest aspen forest and grassland using eddy covariance and carbon isotope techniques; Global Change Biol. 12(2) 294-310.

Running S W, Nemani R R, Heinsch F A, Zhao M, Reeves $\mathrm{M}$ and Hashimoto H 2004 A continuous satellite-derived measure of global terrestrial primary production; BioScience 54(6) 547-560.

Roxburgh S H, Barrett D J, Berry S L, Carter J O, Davies I D, Gifford R M, Kirschbaum M U, McBeth B P, Noble I R and Parton W G 2004 A critical overview of model estimates of net primary productivity for the Australian continent; Funct. Plant. Biol. 31(11) 1043-1059.

Schläpfer F and Schmid B 1999 Ecosystem effects of biodiversity: A classification of hypotheses and exploration of empirical results; Ecol. Appl. 9(3) 893-912.

Sun G, Caldwell P, Noormets A, McNulty S G, Cohen E, Moore Myers J, Domec J C, Treasure E, Mu Q and Xiao J 2011 Upscaling key ecosystem functions across the conterminous United States by a water-centric ecosystem model; J. Geophys. Res. 116 G00J05.

Tian H, Chen G, Liu M, Zhang C, Sun G, Lu C, Xu X, Ren W, Pan S and Chappelka A 2010 Model estimates of net primary productivity evapotranspiration and water use efficiency in the terrestrial ecosystems of the southern United States during 1895-2007; Forest Ecol. Manag. 259(7) 1311-1327.

Townsend A, Braswell B, Holland E and Penner J 1996 Spatial and temporal patterns in terrestrial carbon storage due to deposition of fossil fuel nitrogen; Ecol. Appl. 6(3) 806-814.

Turner D P, Ritts W D, Cohen W B, Gower S T, Running S W, Zhao M, Costa M H, Kirschbaum A A, Ham J M and Saleska S R 2006 Evaluation of MODIS NPP and GPP products across multiple biomes; Remote Sens. Environ. 102(3) 282-292.

Wallace J 2000 Increasing agricultural water use efficiency to meet future food production; Agric. Ecosyst. Environ. 82(1) 105-119.

Yan J, Zhang D, Liu J and Zhou G 2014 Interactions between $\mathrm{CO}_{2}$ enhancement and $\mathrm{N}$ addition on net primary productivity and water-use efficiency in a mesocosm with multiple subtropical tree species; Global Change Biol. 20 2230-2239.

Yuan J, Niu Z and Wang C 2006 Vegetation NPP distribution based on MODIS data and CASA model - a case study of Northern Hebei Province; Chinese Geogr. Sci. 16(4) 334-341.

Zhang Y, Xu M, Chen H and Adams J 2009 Global pattern of NPP to GPP ratio derived from MODIS data: Effects of ecosystem type geographical location and climate; Global Ecol. Biogeogr. 18(3) 280-290.

Zhang F, Ju W, Shen S, Wang S, Yu G and Han S 2012 Variations of terrestrial net primary productivity in East Asia; Terr. Atmos. Ocean Sci. 23(4) 425-437.

Zhao M and Running S W 2010 Drought-induced reduction in global terrestrial net primary production from 2000 through 2009; Science 329 940-943.

Zhao M and Running S W 2011 Response to comments on 'Drought-induced reduction in global terrestrial net primary production from 2000 through 2009'; Science 333 1093.

Zhao F and Yu G 2008 A review on the coupled carbon and water cycles in the terrestrial ecosystems; Progr. Geogr. 27(1) 32-38 (in Chinese). (http://www. progressingeography.com/EN/Y2008/V27/I1/32\#).

Zhao M, Heinsch F A, Nemani R R and Running S W 2005 Improvements of the MODIS terrestrial gross and net primary production global dataset; Remote Sens. Environ. 95(2) 164-176.

Zhao M, Running S W and Nemani R R 2006 Sensitivity of Moderate Resolution Imaging Spectroradiometer (MODIS) terrestrial primary production to the accuracy of meteorological reanalyses; J. Geophys. Res. 111 G01002. 